\title{
Observation of unusual chlorine activation by ground-based infrared and microwave spectroscopy in the late Arctic winter 2000/01
}

\author{
T. Blumenstock ${ }^{1}$, G. Kopp ${ }^{1}$, F. Hase ${ }^{1}$, G. Hochschild ${ }^{1}$, S. Mikuteit ${ }^{1}$, U. Raffalski ${ }^{2}$, and R. Ruhnke ${ }^{1}$ \\ ${ }^{1}$ Institute of Meteorology and Climate Research, Forschungszentrum Karlsruhe and Univ. Karlsruhe, Karlsruhe, Germany \\ ${ }^{2}$ Swedish Institute of Space Physics, Kiruna, Sweden
}

Received: 29 July 2005 - Published in Atmos. Chem. Phys. Discuss.: 14 October 2005

Revised: 13 January 2006 - Accepted: 31 January 2006 - Published: 20 March 2006

\begin{abstract}
During the Arctic winter of 2000/01, groundbased FTIR and millimetre-wave measurements revealed significant amounts of $\mathrm{ClO}$ over Kiruna after the final warming in February 2001. In fact, column amounts of $\mathrm{ClO}$ were still increased in March 2001 when temperatures were about $20 \mathrm{~K}$ above the PSC (Polar Stratospheric Clouds) threshold. At these temperatures, chlorine activation due to heterogeneous processes on PSCs is not possible even in the presence of strong lee wave effects. In order to discuss possible reasons of this feature, time series of other chemical species will be presented and discussed, too. Measurements of HF and $\mathrm{COF}_{2}$ indicated that vortex air was still observed in midMarch 2001. Since the time series of $\mathrm{HNO}_{3}$ column amounts do not give any evidence of a denitrification later than 11 February, chlorine activation persisting for several weeks after the presence of PSCs due to denitrification is rather unlikely. The photolysis of $\mathrm{ClONO}_{2}$-rich air which had been formed at the end of February and beginning of March 2001 as well as chlorine activation due to the presence of an unusual aerosol layer are discussed as possible causes of the increased $\mathrm{ClO}$ column amounts after the final warming.
\end{abstract}

\section{Introduction}

To study ozone-depleting processes and estimate the amount of ozone loss in the Arctic, several international campaigns were performed during the last decade (e.g. Pyle et al., 1994; Von der Gathen et al., 1995; European Commission, 1997; Newman et al., 2002). These campaigns demonstrated chlorine activation whenever stratospheric temperatures were below or close to the PSC formation temperature of about $193 \mathrm{~K}$. After the disappearance of PSCs, ClO is deactivated

Correspondence to: T. Blumenstock

(thomas.blumenstock@imk.fzk.de) by the reaction of $\mathrm{ClO}$ with $\mathrm{NO}_{2}$ forming $\mathrm{ClONO}_{2}($ Oelhaf et al., 1994). This was observed by many instruments, for example by ground-based FTIR spectrometers and millimetrewave radiometers at Kiruna during the last 10 winters (Blumenstock et al., 2003; Kopp et al., 2003). The typical time scale of deactivation is about 10 days. However, column amounts of $\mathrm{ClO}$ were still increased in March 2001 when temperatures were about $20 \mathrm{~K}$ above the PSC threshold.

The winter of 2000/01 was unusual: The break-up of the vortex took a long time and allowed to observe aged vortex air several weeks after final warming. Another very interesting observation was made by aerosol lidars in the winter 2000/01. From November 2000 until February 2001, an aerosol layer in the stratosphere was detected consistently by several stations (Gerding et al., 2003). Although these observation campaigns have been made since the late eighties, such an aerosol layer has never been observed before. A possible correlation with our observations shall be discussed.

\section{Instrument and model description}

Ground-based atmospheric observations are made at the Swedish Institute of Space Physics (IRF; $67.8^{\circ} \mathrm{N}, 20.4^{\circ} \mathrm{E}$, 419 m a.s.l.) in Kiruna. This site is well suited for groundbased Arctic measurements due to its high tropospheric transmission over long periods in winter and spring. Furthermore, this site is situated inside as well as outside the polar vortex in the course of the winter, which allows for the study of ozone loss and mixing processes. The polar night at this site is quite short. Consequently, FTIR measurements of solar absorption are normally interrupted for less than two months. Measurements of chlorine monoxide (ClO) using FTIR as well as microwave FTIR spectroscopy are a well-established technique (De Zafra et al., 1994; Bell et al., 1996).

Published by Copernicus GmbH on behalf of the European Geosciences Union. 


\subsection{Fourier transform infrared spectrometer (FTIR)}

Within the framework of the NDSC (Network for the Detection of Stratospheric Change), infrared solar absorption spectra have been recorded routinely at Kiruna since March 1996. A Bruker 120 HR spectrometer with a maximum optical path difference of $360 \mathrm{~cm}$ is used, yielding a spectral resolution of up to $0.0025 \mathrm{~cm}^{-1}$. Typically, a spectral resolution of $0.005 \mathrm{~cm}^{-1}$ is applied. Spectra are coadded for up to 15 min during noon and 5 min during sunrise and sunset in order to limit the variation of the solar zenith angle to $0.2^{\circ}$. The signal to noise ratio in the linefree continuum amounts to several hundreds. This results in a signal to noise ratio of several hundreds for the signatures of the constituents discussed in this paper, except for $\mathrm{ClO}$. This species has far weaker signatures which are in the order of the noise level. The error bars shown in the figures represent the error due to noise in the spectrum. An NDSC side by side intercomparison was performed successfully in March 1998 (Meier et al., 2005) and the differences found were less than $3 \%$ for all compared species.

The FTIR spectra were analysed with the inversion program PROFFIT (PROFile FIT) (Hase, 2000; Hase et al., 2004) using the forward model KOPRA (Karlsruhe Optimized Precise Radiative transfer Algorithm) (Höpfner et al., 1998; Kuntz et al., 1998; Stiller et al., 1998). The synthetic spectra were calculated using daily pressure and temperature data of the National Centers for Environmental Prediction (NCEP) (Kanamitsu, 1989). Spectroscopic data were taken from the HITRAN 2000 database (Rothman et al., 2003). Using the inversion code PROFFIT, profiles were retrieved from the absorption line shape with the Optimal Estimation Method of Rodgers (Rodgers, 1970, 1976, 1990), the PhillipsTikhonov approach (Phillips, 1962; Tikhonov, 1963), or scaling of a-priori profiles in user-defined altitude intervals. For most of the species, profile retrievals were performed. Analysis of the averaging kernels indicated three to four independent layers from the ground up to $35 \mathrm{~km}$ in case of $\mathrm{O}_{3}, \mathrm{HNO}_{3}, \mathrm{HCl}$, and $\mathrm{HF}$. The instrumental line shape (ILS) needed for an accurate retrieval was derived from regular cell measurements using the LINEFIT software (Hase et al., 1999).

For $\mathrm{ClONO}_{2}, \mathrm{NO}_{2}, \mathrm{COF}_{2}$, and $\mathrm{ClO}$, scaling of the apriori profile was performed. The retrieval strategy for $\mathrm{ClO}$ was adopted from Hase (2000). In case of $\mathrm{ClO}$, the lower more variable peak around $20 \mathrm{~km}$ only was scaled by the fitting procedure, while the upper part of the profile was kept constant. For $\mathrm{ClO}, 7$ microwindows (MW) were fitted simultaneously: 819 261-819 550, 822 000-822 700, 823 550$823800, \quad 829150-829400, \quad 830400-830811, \quad 831800-$ 832100 , and $833200-833600 \mathrm{~cm}^{-1}$. The $\mathrm{ClO}$ lines and $\mathrm{mi}-$ crowindows selected were similar to those used by Bell et al. (1996) and Rinsland et al. (1992). The error bar of the FTIR data shows the error due to spectral noise and is given as $1-\sigma$ error. While for other species this error is quite small it is the dominant one in case of $\mathrm{ClO}$. For $\mathrm{ClO}$ column amounts this error amounts to about $30 \%$.

\subsection{Millimetre-wave radiometer (MIRA)}

The millimetre-wave observations were performed with the groundbased millimetre-wave radiometer MIRA-2. It was constructed at the Forschungszentrum Karlsruhe and is capable of measuring $\mathrm{O}_{3}, \mathrm{ClO}, \mathrm{HNO}_{3}$, and $\mathrm{N}_{2} \mathrm{O}$ in the frequency range from 268 to $281 \mathrm{GHz}$. MIRA-2 measures in the emission geometry in northward direction. A Schottky diode mixer converts the signal to an intermediate frequency of $1.5-2.7 \mathrm{GHz}$. The receiver noise temperature is about $800 \mathrm{~K}$. Spectral analysis is performed by an acousto-optical spectrometer with a spectral resolution of about $1.2 \mathrm{MHz}$. For balanced calibration an internal adjustable reference load is used. A detailed description of the system is given in Berg et al. (1998). The measured spectra are integrated either until the noise of the resulting spectrum is at least ten times smaller than the intensity of the signature of the desired trace gas or until the noise is significantly smaller than baseline artifacts. Integration times depend on the tropospheric conditions and typically range from 0.5 to $1 \mathrm{~h}$ for ozone up to 3 to $4 \mathrm{~h}$ for $\mathrm{ClO}$.

The radiative transfer model uses spectroscopic data taken from the HITRAN 96 database (Rothman et al., 1998), except for ClO. For this species, spectroscopic data from the JPL catalogue (Pickett et al., 1998) and the JPL measurement made in 1992 for the pressure broadening coefficient were used. For the temperature dependence of the pressure broadening parameter, the measurements of Oh and Cohen (1994) were applied. The daily profiles of pressure and temperature from the National Centers for Environmental Prediction (NCEP) (Kanamitsu, 1989) were taken for the forward calculations. Retrieval was carried out using a modified Optimal Estimation Method (Rodgers, 1970, 1976, 1990), including the simultaneous retrieval of several constituents within the same inversion process (Kuntz et al., 1999), and the fit of sinusoidal undulations caused by standing waves within the inversion (Kuntz et al., 1997). With these methods, volume mixing ratio (vmr) profiles can be retrieved in the altitude range from about 17 to $55 \mathrm{~km}$. Using the full width at half maximum (FWHM) of the averaging kernels as a criterion, a vertical resolution of the $\mathrm{ClO}$ profiles of at best $10 \mathrm{~km}$ can be achieved.

The typical uncertainty is about $0.5 \mathrm{ppbv}$, caused by errors due to thermal noise, standing waves, and systematic errors (Kopp, 2000). In addition, day-night difference spectra were calculated and analysed when available. An error estimate for these profiles shows a systematic error of about $0.08 \mathrm{ppbv}$ and a random error of about $0.02 \mathrm{ppbv}$ and a total error of about $0.1 \mathrm{ppbv}$. The systematic error includes errors of pointing, calibration, temperature and spectroscopic data. Since some error sources like standing waves nearly cancel out the error is reduced significantly. 

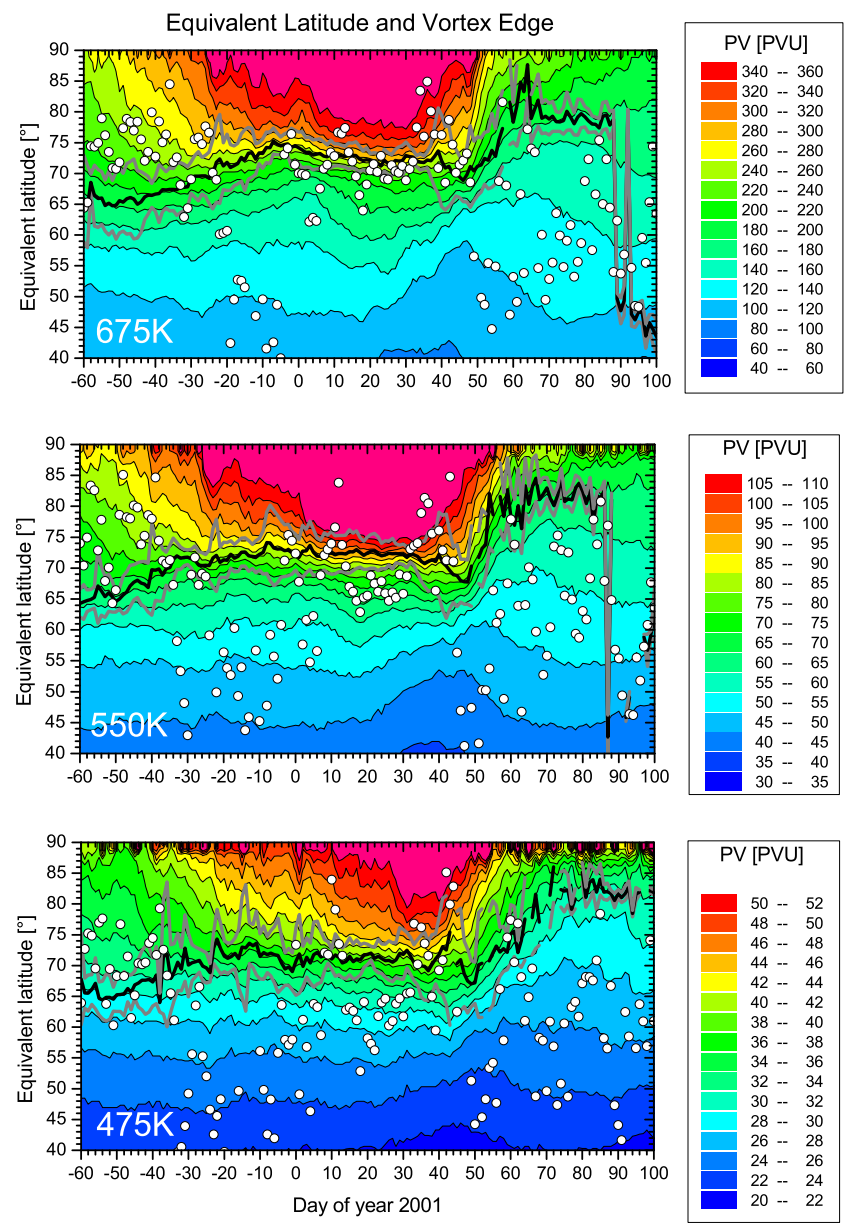

Fig. 1. The evolution of the polar vortex in equivalent latitudes during the Arctic winter $2000 / 01$ on the 675 , 550, and $475 \mathrm{~K}$ isentropic level (based on ECMWF T213 data). The grey lines indicate the inner and outer edge of the vortex, respectively, while the black line describes the mean vortex edge. The colour coding shows the strength of the vortex in PVU $\left(10^{-6} \mathrm{~km}^{2} / \mathrm{kgs}\right)$. The open circles depict the PV over Kiruna, showing its position relative to the vortex.

2.3 The Karlsruhe simulation model of the middle atmosphere (KASIMA)

The 3D CTM KASIMA (KArlsruhe SImulation model of the Middle Atmosphere) used in this study has a unique model architecture, as it couples a mechanistic model with an offline model forced by meteorological analyses (Kouker et al., 1999). The distribution of chemical species in this model run was initialised on 11 March , 1999, with 2-D model data of the MPI for Chemistry in Mainz. The meteorology was based on operational ECMWF analyses up to $1 \mathrm{hPa}$ and the prognostic model on top. The horizontal resolution is approximately $5.6 \times 5.6$ degrees $(\mathrm{T} 21)$. In the vertical regime, 63 levels between 10 and $120 \mathrm{~km}$ pressure altitude and a $0.75 \mathrm{~km}$ spacing from 10 up to $22 \mathrm{~km}$ with an exponential increase above were used. For comparison with FTIR and

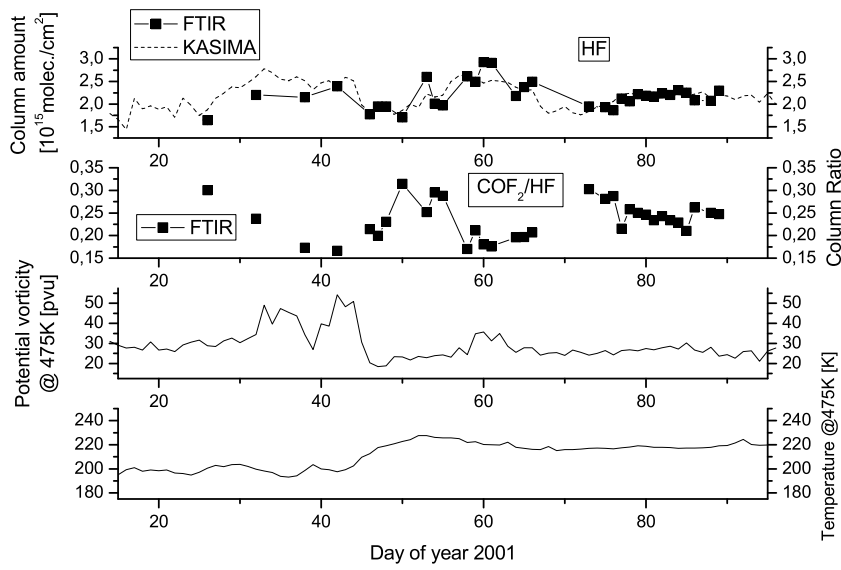

Fig. 2. Time series of HF column amounts and of $\mathrm{COF}_{2}$ to $\mathrm{HF}$ column ratios as measured by FTIR along with temperature and potential vorticity (ECMWF data) on the $475 \mathrm{~K}$ level above Kiruna in the winter of 2000/01.

MIRA data, the model output for 12:00 UT each day during the simulation was used.

\section{The Arctic vortex in the winter of 2000/01}

Figure 1 shows the evolution of the Arctic vortex in the winter of 2000/01 on different isentropic levels using the equivalent latitude method as suggested by Nash et al. (1996). The equivalent latitude is a measure of the area enclosed by a given value of the potential vorticity (PV) of the polar vortex ideally centered on the pole. The colour index of the graphs gives the PV of the idealised vortex at the corresponding equivalent latitude. The grey lines are the inner and outer vortex edge and describe the strongest curvature of the PV plotted versus the equivalent latitude on the respective day. The black line is the mean vortex edge and given by the steepest gradient in the plot of the PV versus equivalent latitude on the respective day. The open circles depict the position of Kiruna relative to the polar vortex, the colour index below the circles corresponds to the PV over Kiruna on the respective day and isentropic level. ECMWF T213 data were used for these calculations.

From early December to mid-February, there was an Arctic vortex with well-defined vortex edges, especially at higher altitudes (Fig. 1). In comparison to other Arctic winters when the mean vortex edge reached equivalent latitudes of about $60^{\circ}$, the vortex of the 2000/01 Arctic winter was smaller and weaker. In February 2001, vortex break-up during the final warming led to a drastic loss of area of the polar vortex. Later on, the criteria for the determination of the vortex edges did not yield any unique solution resulting in oscillations of the vortex boundary or failed completely.

In the winter of 2000/01, the stratospheric conditions were divided into 2 phases: until mid-February, there was 


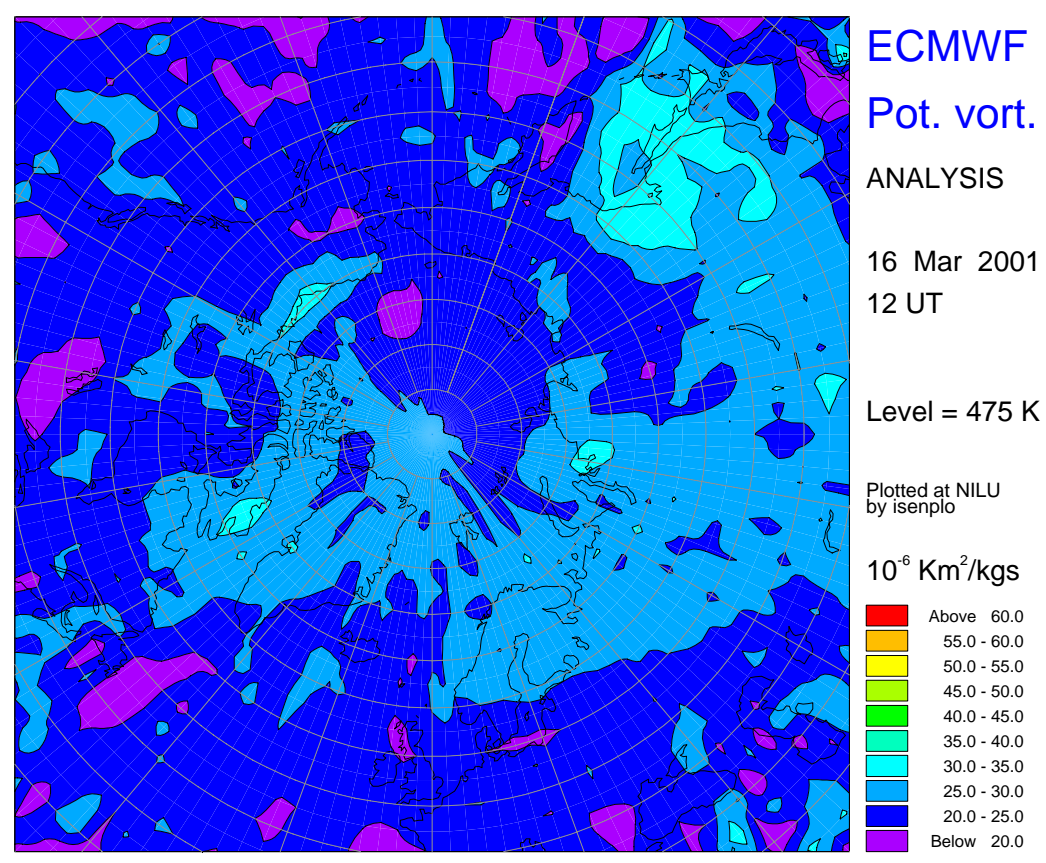

Fig. 3. Contour plot of the polar vortex for the $475 \mathrm{~K}$ level on 16 March, 2001.

a well-defined polar vortex and the temperatures were occasionally below PSC temperature. After major warming in mid-February, temperatures increased and the vorticity decreased strongly (Fig. 2). During March, the vortex dissolved over a long period; a vorticity contour plot from 16 March 2001 that is typical of almost the entire March 2001 is shown in Fig. 3.

Since HF has a long life time, it is used as a dynamic tracer. In other winters, HF column amounts correlate well with potential vorticity. In this case, column amounts of $\mathrm{HF}$ add up to about $1.5 \times 10^{15}$ molec $\mathrm{cm}^{-2}$ outside and about $2.5 \times 10^{15} \mathrm{molec}^{-2}$ inside the vortex. In March 2001, however, the column amounts of HF were still larger than $2 \times 10^{15}$ molec $\mathrm{cm}^{-2}$. This indicates that subsided air masses were still observed, although the potential vorticity was lower than $30 \mathrm{PVU}\left(10^{-6} \mathrm{~km}^{2} / \mathrm{kgs}\right)$ on the $475 \mathrm{~K}$ level (Fig. 2).

Another quite sensitive indicator for vortex air is the ratio of $\mathrm{COF}_{2}$ to $\mathrm{HF}$. Since $\mathrm{COF}_{2}$ is released first by photolysis of CFCs and its life time is about half a year before it is converted to HF, the ratio of these species is an indicator for the age of the air. This means that low ratios indicate "old" air masses or, in other words, old polar vortex air. This was observed around days 40 and 60 and in mid-March (Fig. 2).

\section{Observation of unusual chlorine activation}

The time series of $\mathrm{ClO}$ column amounts over Kiruna as measured by FTIR and MIRA in the Arctic winter of 2000/01 and calculated by KASIMA together with possible PSC con- tact hours and minimum temperatures at $30 \mathrm{hPa}$ are shown in Fig. 4. Before mid-February, increased amounts of $\mathrm{ClO}$ were observed periodically due to chlorine activation on PSCs, correlating well with low stratospheric temperatures and possible PSC contact times. Similar observations had been made in earlier winters, for example in the winter of 1999/2000 (e.g. Kopp et al., 2003).

In mid-February, the final warming occurred and stratospheric temperatures strongly increased. Enhanced amounts of ClO, however, were still observed in March 2001, 4 weeks after the final warming. This behaviour differed from previous winters when low stratospheric temperatures and contact to PSCs had been a precondition of enhanced $\mathrm{ClO}$ columns (European Commission, 1997). MIRA detected significantly increased $\mathrm{ClO}$ amounts on 16 and 17 March. This is the most striking finding of the time series of stratospheric compounds presented in this paper (Fig. 4).

Difference microwave spectra (day-night) were calculated for observation days with sufficiently stable tropospheric conditions (Fig. 5). Signatures of interfering species without diurnal variation are mostly diminished in these difference spectra, whereas signatures of $\mathrm{ClO}$ remain and are visible in the difference spectra of 6 February and 17 March. In contrast to this, $\mathrm{ClO}$ is hardly visible in the spectrum of 16 February. The profiles retrieved from these difference spectra are presented in Fig. 6 and also show enhanced volume mixing ratios of $\mathrm{ClO}$ in the lower stratosphere on 6 February and 17 March. However, the maximum concentration in the profile of 17 March is found in an altitude which is about $3 \mathrm{~km}$ lower than that of the spectrum of 6 February. Some $\mathrm{ClO}$ is also found in the middle stratosphere which is probably due 

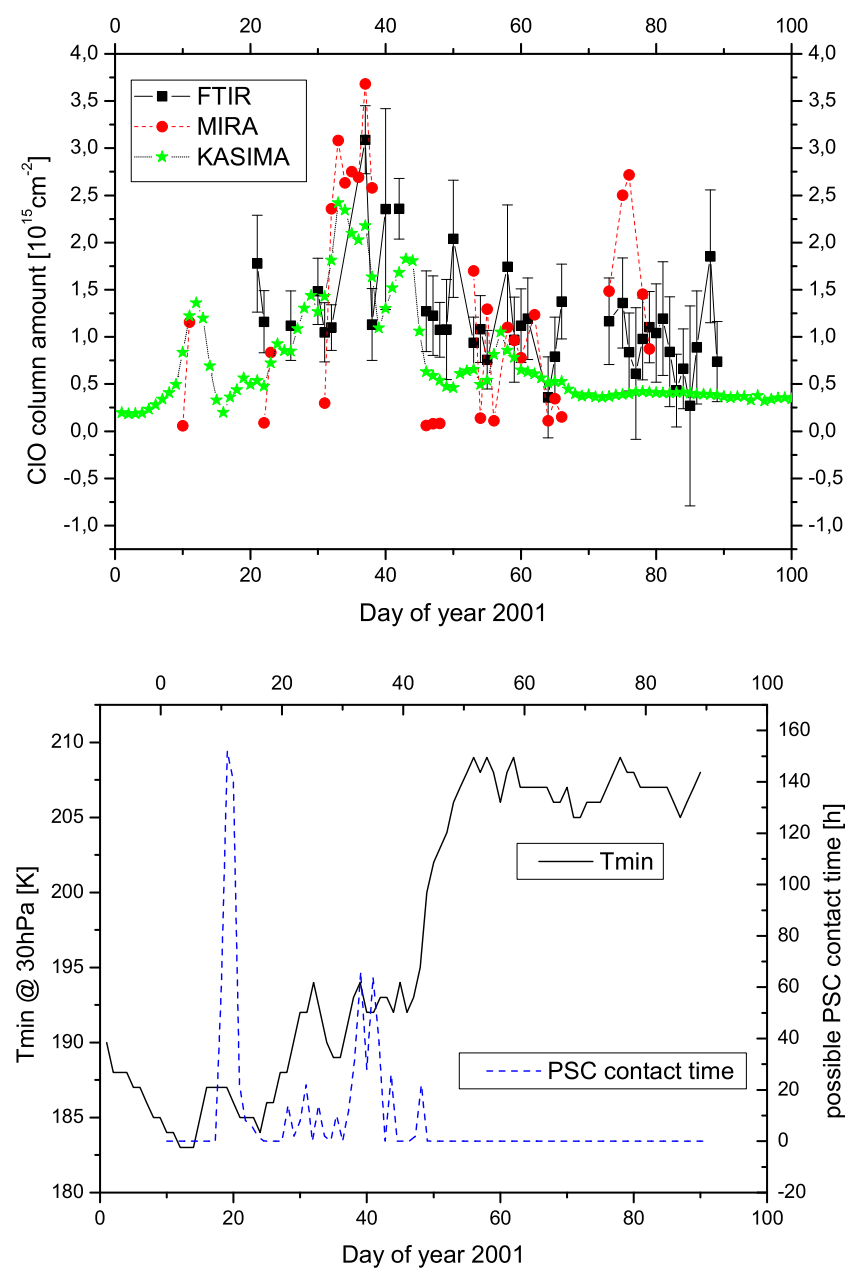

Fig. 4. Time series of column amounts of $\mathrm{ClO}$ as measured by FTIR and MIRA and calculated by KASIMA together with possible contact hours with PSCs and the minimum stratospheric temperature (ECMWF data).

to the photolysis of $\mathrm{ClONO}_{2}$. Furthermore, the day-night difference spectrum of 6 February shows an unusual shape which is different from the typical shape in the case of chlorine activation by PSCs. This corresponds to $\mathrm{ClO}$ in altitudes above $25 \mathrm{~km}$, higher than the usual PSC occurrence.

In general, the agreement of MIRA and FTIR is quite good (Fig. 4). Time series of $\mathrm{ClO}$ from previous winters also showed a good agreement of MIRA and FTIR (Kopp et al., 2003). On 6 February, in particular, both instruments clearly detected increased amounts of $\mathrm{ClO}$. On 16 and 17 March, FTIR measured slightly increased amounts of $\mathrm{ClO}$, but lower amounts as compared to MIRA. However, it must be considered that errors in $\mathrm{ClO}$ measurements by FTIR are quite large and that the instruments are looking in opposite azimuthal directions. This may cause some difference, especially if there are some inhomogeneities in the vortex. Unfortunately, due to the lack of night time measurements, day-night differences of FTIR spectra cannot be calculated.

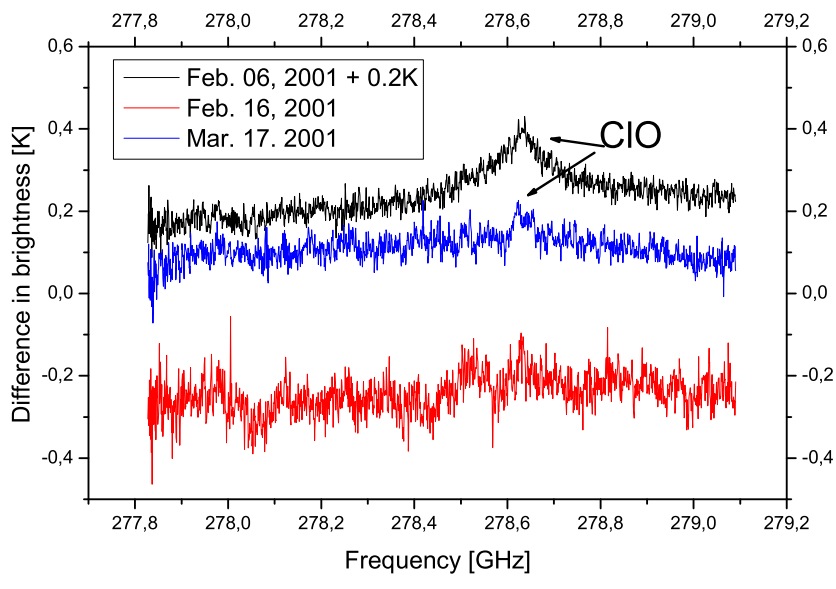

Fig. 5. Difference microwave spectra (day- night) for some days of observation. The spectrum of 6 February has been shifted by $0.2 \mathrm{~K}$ for clarity. Difference spectra from 16 February and 17 March, 2001, clearly show a signature of $\mathrm{ClO}$.

The mean column amount and standard deviation of the data from 14 March to 20 March is $(1.81+/-0.78) \times 10^{15} \mathrm{molec} \mathrm{cm}^{-2}$ for MIRA results, $(1.01+/-0.26) \times 10^{15} \mathrm{molec} \mathrm{cm}^{-2}$ for FTIR, and $(0.40+/-0.02) \times 10^{15} \mathrm{molec} \mathrm{cm}^{-2}$ for KASIMA, respectively. From 14 to 20 March $\mathrm{ClO}$ column amounts obtained from MIRA are about a factor of 5 increased as compared to model data. During this period MIRA results are about a factor of 10 larger as compared to periods with no chlorine activation (Fig. 4).

To our knowledge, increased $\mathrm{ClO}$ levels in the late Arctic winter 2000/01 were not observed and reported by other instruments. This might be due to the absence of extended field campaigns during this winter. Moreover, most balloon and aircraft missions were conducted in January during the cold period of this winter. In mid-March 2001, no enhanced levels of $\mathrm{OClO}$ were observed by GOME (Wilms-Grabe et al., 2003).

Very few observations of chlorine activation outside the vortex are reported in literature: $\mathrm{OClO}$ formation on stratospheric sulphate aerosols, whose number density was increased due to the eruption of Pinatubo (Solomon et al., 1993; Perner et al., 1994). Enhanced levels of OClO and BrO outside the vortex were observed by Erle et al. (1998) in 1994 when sulphate aerosol loading was close to background levels. They suggested a heterogeneous activation of $\mathrm{BrONO}_{2}$ on sulphuric acid aerosols at temperatures of about 200 to $210 \mathrm{~K}$. Enhanced $\mathrm{ClO}$ mixing ratios were detected by Raffalski et al. (1998) in April 1997.

While KASIMA agrees quite well with the observations prior to the final warming, KASIMA does not reproduce increased amounts of $\mathrm{ClO}$ in March. Other models like SLIMCAT or REPROBUS do not show enhanced amounts of $\mathrm{ClO}$ in March either (Harris, 2001). This demonstrates that cur- 


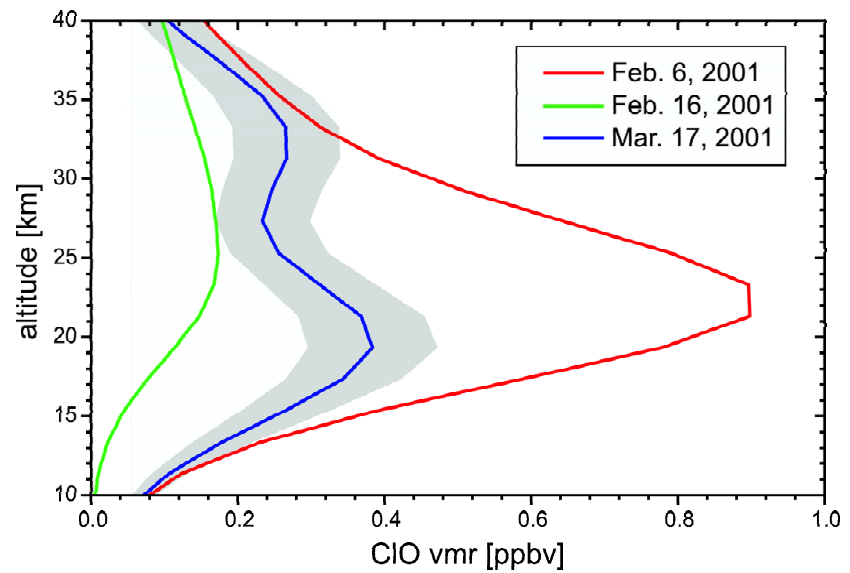

Fig. 6. Profiles retrieved from difference microwave spectra (daynight) for some days of observation. Shaded area show random and systematic error.

rent knowledge cannot describe the chlorine activation observed by the two independent techniques.

Since stratospheric temperatures were about $20 \mathrm{~K}$ above the PSC threshold, chlorine activation on PSCs was not possible even in the presence of strong lee wave effects. Therefore, the following explanations were considered:

1. Long-lasting activation due to denitrification.

2. Photolysis of $\mathrm{ClONO}_{2}$ in deactivated air masses within the dissolving vortex.

3. Chlorine activation on non-PSC aerosols.

\subsection{Long-lasting chlorine activation due to denitrification?}

For the chlorine activation to persist over several weeks after the presence of PSCs, denitrification is needed. In order to investigate denitrification processes in the winter 2000/01, $\mathrm{HNO}_{3}$ and $\mathrm{NO}_{2}$ are shown in Fig. 7. The time series of $\mathrm{HNO}_{3}$ columns as well as the ratio to HF do not reveal any significant denitrification in March 2001. When comparing the $\mathrm{HNO}_{3}$ to $\mathrm{HF}$ ratio with that of previous winters and considering the decrease towards the end of the winter by photolysis of $\mathrm{HNO}_{3}$, it may well be assumed that there might have been some dentrification on day 42 or in January only.

Due to the photolysis of $\mathrm{HNO}_{3}, \mathrm{NO}_{2}$ increased towards the end of the winter. This had been observed in many previous winters. Therefore, the $\mathrm{NO}_{2}$ in the stratosphere was expected to be sufficient to recombine $\mathrm{ClO}$ to $\mathrm{ClONO}_{2}$. This was also calculated with KASIMA. Furthermore, the increase of $\mathrm{NO}_{2}$ in March 2001 supports the statement that denitrification did not occur and affect the stratosphere at that time. So, chlorine activation lasting since mid-February is quite unlikely to be the reason of enhanced levels of $\mathrm{ClO}$ in March 2001.
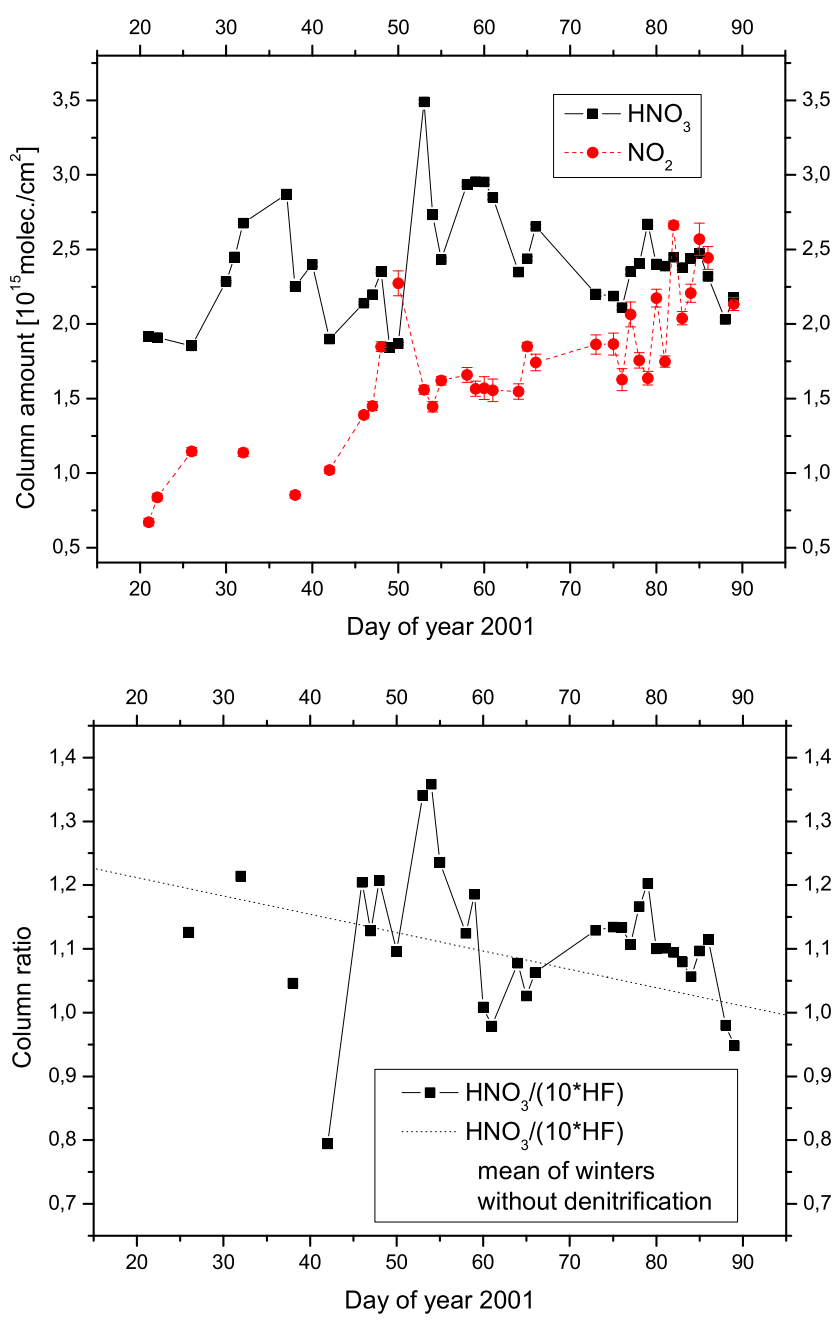

Fig. 7. Time series of column abundances of $\mathrm{HNO}_{3}$ and $\mathrm{NO}_{2}$ and of column ratios of $\mathrm{HNO}_{3}$ to $\mathrm{HF}$ as measured by FTIR in the winter of 2000/01.

\subsection{Photolysis of chlorine nitrate $\left(\mathrm{ClONO}_{2}\right)$}

Another explanation considered was the photolysis of $\mathrm{ClONO}_{2}$. The time series of $\mathrm{ClONO}_{2}$ had a maximum on 1 and 2 March, 2001 (Fig. 8). An increase of $\mathrm{ClONO}_{2}$ in the late polar vortex, in particular in the vortex edge region, had been observed in most of the previous winters (European Commission, 1997). If $\mathrm{ClONO}_{2}$ was the source of enhanced levels of $\mathrm{ClO}$ in mid-March, the amount of $\mathrm{ClONO}_{2}$ should decrease on a slower time scale than observed. And in this case it should be a feature of the dissolving vortex and be observable in other late winters, too. KASIMA model runs also suggest that the amount of $\mathrm{ClONO}_{2}$ is reduced quickly and enhanced levels of $\mathrm{ClONO}_{2}$ are not calculated after the final warming. While Fig. 8 shows KASIMA results for Kiruna only, enhanced levels of $\mathrm{ClONO}_{2}$ are not calculated anywhere else in March 2001. Based on the current knowledge, 


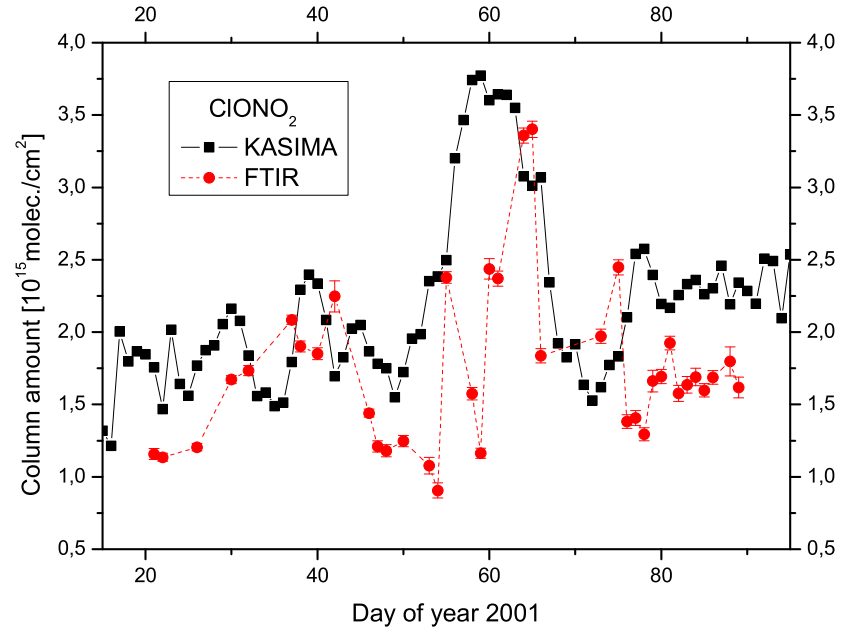

Fig. 8. Time series of column abundances of $\mathrm{ClONO}_{2}$ as measured by FTIR and calculated by KASIMA.

heterogeneous processes and, hence, particles are necessary to activate chlorine.

\subsection{Chlorine activation on non-PSC aerosols}

Gerding et al. (2003) observed an unusual aerosol layer in the middle stratosphere at four different Arctic lidar stations in winter 2000/01. These stations are Ny-Ålesund $\left(79^{\circ} \mathrm{N}, 12^{\circ} \mathrm{E}\right)$, Søndre Strømfjord $\left(67^{\circ} \mathrm{N}, 51^{\circ} \mathrm{W}\right)$, Andenes $\left(69^{\circ} \mathrm{N}, 16^{\circ} \mathrm{E}\right)$, and Kiruna $\left(68^{\circ} \mathrm{N}, 20^{\circ} \mathrm{E}\right)$. The layer had a thickness of about $3 \mathrm{~km}$ and descended from $38 \mathrm{~km}$ on 16 November 2000, to $26 \mathrm{~km}$ on 12 February 2001. Gerding et al. (2003) reported a sedimentation rate of $155 \mathrm{~m} / \mathrm{d}$. If sedimentation would have continued until March, an altitude of about $22 \mathrm{~km}$ would have resulted. As shown in Fig. 6, the increase of $\mathrm{ClO}$ in March occurred at altitudes between $19.5 \mathrm{~km}$ and $22.5 \mathrm{~km}$. In February part of the chlorine activation might be due to PSCs which form at altitudes well below the unusual aerosol layer during that time. But as discussed above significant values of $\mathrm{ClO}$ were found above the typical height of PSCs which is consistent with the altitude of the aerosol layer in February. The lower altitude of the $\mathrm{ClO}$ maximum in the March measurement is also consistent to a further sedimentation of the aerosol layer.

The lidar measurements revealed that the particle size was between 30 and $50 \mathrm{~nm}$ and that the particles were solid. The authors suggested that the particles consisted of soot, $\mathrm{Al}_{2} \mathrm{O}_{3}$, $\mathrm{SiO}_{2}$, or iron particles. Such particles might have been injected by rocket exhaust or meteoric dust. The total mass of the layer was roughly estimated to be 200 to $2000 \mathrm{~kg}$. Various investigations were published about heterogeneous chemical reactions on rocket exhaust particles (e.g. Jones et al., 1995; Jackman et al., 1998). A more recent study shows that meteoritic dust particles entering the Earth's atmosphere might be larger than expected (Klekociuk et al., 2005). Thus, one possible explanation of the enhanced $\mathrm{ClO}$ values measured in March might be chlorine activation on the aerosols of the unusual aerosol layer observed by the lidar instruments.

After mid-December, the entire vortex area was filled with the aerosol, but no sign of the aerosol layer could be detected outside the vortex. This layer was observed until 12 February 2001. No observations of this layer were made after the vortex break-up. However, it is reasonable that the particles were still in the stratosphere, but thinned out by mixing processes. In fact, the FTIR measurements of $\mathrm{HF}$ and $\mathrm{COF}_{2}$ indicate that residuals of vortex air masses were over Kiruna on the respective days and it is plausible to assume that residuals of the aerosol layer were over Kiruna on these days.

\section{Conclusions}

Enhanced levels of $\mathrm{ClO}$ were observed above Kiruna in March 2001. Since stratospheric temperatures were about $20 \mathrm{~K}$ above the PSC threshold, chlorine activation due to heterogeneous processes on PSCs was impossible even in the presence of strong lee wave effects. As no signs of denitrification were seen later than 11 February, chlorine activation persisting over several weeks after the presence of PSCs due to denitrification was rather unlikely. Another source of $\mathrm{ClO}$ discussed in this paper is the photolysis of $\mathrm{ClONO}_{2}$-rich air which had formed at the end of February and beginning of March 2001. However, such processes had not been observed in other winters.

Another possibility is chlorine activation on the surface of particles of an unusual aerosol layer consisting of rocket exhaust or meteoric dust, which was observed inside the Arctic vortex by several lidars between November 2000 and February 2001. Later on, no aerosol lidar observations were made at Kiruna. Therefore, a clear correlation cannot be proven. However, such an aerosol layer had not been observed in previous winters, although lidar observations have been made since the late eighties. This means that two unusual observations coincided in winter 2000/01, which both were unique in their corresponding 10-years time series.

Acknowledgements. We would like to thank the European Centre for Medium-Range Weather Forecasts (ECMWF) for providing meteorological data, potential vorticity data for the calculation of equivalent latitude and PT data for model simulations. Furthermore, we are grateful to the Goddard Space Flight Center for providing the temperature and pressure profiles of the National Centers for Environmental Prediction used for inversion via the automailer system.

Edited by: C. George 


\section{References}

Bell, W., Paton-Walsh, C., Gardiner, T. D., Woods, P. T., Swann, N. R., Martin, N. A., Donohoe, L., and Chipperfield, M. P.: Measurements of stratospheric chlorine monoxide $(\mathrm{ClO})$ from ground-based FTIR observations, J. Atmos. Chem., 24, 285-297, 1996.

Berg, H., Krupa, R., Hochschild, G., Kopp, G., and Kuntz, M.: Millimetre wave radiometer with adjustable internal calibration load for high resolution measurements of stratospheric constituents, Proceedings of the 2nd ESA Workshop on Millimetre Wave Technology and Applications: Antennas, Circuits and Systems, 372-377, Espoo, May 1998.

Blumenstock, T., Hase, F., Griesfeller, A., Ruhnke, R., Fischer, H., Raffalski, U., and Kondo, Y.: Chlorine activation, ozone loss and sequestration of nitric acid in PSCs as observed by groundbased FTIR measurements during winter at Kiruna (Sweden) since winter 1993/94, Proceedings of the Sixth European Workshop on Polar Stratospheric Ozone, Gothenborg 2002, European Commission-Air pollution research report 79, 51-54, 2003.

De Zafra, R., Emmons, L. K., Reeves, J. M., and Shindell, D. T.: An overview of millimeter-wave spectroscopic measurements of chlorine monoxide at Thule, Greenland, February-March 1992: Vertical profiles, diurnal variation, and longer-term trends, Geophys. Res. Lett., 21, 1271-1274, 1994.

Erle, F., Grendel, A., Perner, D., Platt, U., and Pfeilsticker, K.: Evidence of heterogeneous bromine chemistry on cold stratospheric sulphate aerosols, Geophys. Res. Lett., 25, 4329-4332, 1998.

European Commission: European Research in the Stratosphere The Contribution of EASOE and SESAME to our current understanding of the ozone layer, Report EUR 16986 EN, Off. for Off. Publ. of the Eur. Commun., Luxembourg, 1997.

Gerding, M., Baumgarten, G., Blum, U., Thayer, J. P., Fricke, K. H., Neuber, R., and Fiedler, J.: Observation of an unusual midstratospheric aerosol layer in the Arctic: Possible sources and implications for polar vortex dynamics, Ann. Geophys., 21, 10571069, 2003.

Harris, N. R. P.: The Northern Hemisphere Stratosphere in the 2000/01 Winter, Report of the European Ozone Research Coordinating Unit, see http://www.ozone-sec.ch.cam.ac.uk, 2001.

Hase, F., Blumenstock, T., and Paton-Walsh, C.: Analysis of instrumental line shape of highresolution FTIRspectrometers using gas cell measurements and a new retrieval software, Appl. Opt., 38, 3417-3422, 1999.

Hase, F.: Inversion von Spurengasprofilen aus hochaufgelösten bodengebundenen FTIR-Messungen in Absorption, Wissenschaftliche Berichte, FZK Report No. 6512, Forschungszentrum Karlsruhe, Germany, 2000.

Hase, F., Hannigan, J. W., Coffey, M. T., Goldman, A., Höpfner, M., Jones, N. B., Rinsland, C. P., and Wood, S. W.: Intercomparison of retrieval codes used for the analysis of high-resolution, ground-based FTIR measurements, J. Quant. Spectrosc. \& Rad. Transfer, 87, 25-52, 2004.

Höpfner M., Stiller, G. P., Kuntz, M., von Clarmann, T., Echle, G., Funke, B. Glatthor, N., Hase, F., Kemnitzer, H., and Zorn, S.: The Karlsruhe optimized and precise radiative transfer algorithm, Part II: Interface to retrieval applications, SPIE Proceedings, 3501, 186-195, 1998.

Jackman, C. H., Considine, D. B., and Fleming, E. L.: A global modelling study of solid rocket aluminium oxide emission ef- fects on stratospheric ozone, Geophys. Res. Lett., 25, 907-910, 1998.

Jones, A. E., Bekki, S., and Pyle, J. A.: On the atmospheric impact of launching the Ariane 5 rocket, J. Geophys. Res., 100, $16651-$ 16660, 1995.

Kanamitsu, M.: Description of the NMC global data assimilation and forecast system, Weather and Forecasting, Vol. 4, 335-342, 1989.

Klekociuk, A. R., Brown, P. G., Pack, D. W., ReVelle, D. O., Edwards, W. N., Spalding, R. E., Tagliaferri, E., Yoo, B. B., and Zagari, J.: Meteoritic dust from the atmospheric disintegration of a large meteoroid, Nature, 436, 1132-1135, 2005.

Kopp, G.: Inversion arktischer stratosphärischer Spurengasprofile für die Ozonforschung aus Messungen eines bodengebundenen Millimeterwellenradiometers, FZK Report No. 6563, Forschungszentrum Karlsruhe, Germany, 2000.

Kopp, G., Berg, H., Blumenstock, T., Fischer, H., Hase, F., Hochschild, G., Höpfner, M., Kouker, W. Reddmann, T., Ruhnke, R., Raffalski, U., and Kondo, Y.: Evolution of ozone and ozone related species over Kiruna during the THESEO 2000SOLVE campaign retrieved from ground-based millimeter wave and infrared observations, J. Geophys. Res., 108(D5), 83088319, 2003.

Kouker, W., Langbein, I., Reddmann, T., and Ruhnke, R.: The Karlsruhe Simulation Model of the Middle Atmosphere (KASIMA), Version 2, FZK Report 6278, Forschungszentrum Karlsruhe, Germany, 1999.

Kuntz, M., Hochschild, G., and Krupa, R.: Retrieval of ozone mixing ratio profiles from groundbased millimetre wave measurements disturbed by standing waves, J. Geophys. Res., 102, 21 965-21 975, 1997.

Kuntz M., Höpfner, M., Stiller, G. P., von Clarmann, T., Echle, G., Funke, B., Glatthor, N., Hase, F., Kemnitzer, H., and Zorn, S.: The Karlsruhe optimized and precise radiative transfer algorithm, Part III: ADDLIN and TRANSF algorithms for modeling spectral transmittance and radiance, SPIE Proceedings, 3501, 247256, 1998.

Kuntz, M., Kopp, G., Berg, H., Hochschild, G., and Krupa, R.: Joint retrieval of atmospheric constituent profiles from groundbased millimetre wave measurements: $\mathrm{ClO}, \mathrm{HNO}_{3}, \mathrm{~N}_{2} \mathrm{O}$, and $\mathrm{O}_{3}, \mathrm{~J}$. Geophys. Res., 104, 13 981-13 992, 1999.

Meier, A., Paton-Walsh, C., Bell, W., Blumenstock, T., Hase, F., Goldman, A., Steen, A., Kift, R., Woods, P., and Kondo, Y.: Evidence of reduced measurement uncertainties from an FTIR instrument intercomparison at Kiruna, Sweden, J. Quant. Spectrosc. \& Rad. Transfer, 96, 75-84, 2005.

Nash, E. R., Newman, P. A., Rosenfield, J. E., Schoeberl, M. R.: An objective determination of the polar vortex using Ertel's potential vorticity, J. Geophys. Res., 101(D5), 9471-9478, 1996.

Newman, P. A., Harris, N. R. P., Adriani, A., Amanatidis, G. T., Anderson, J. G., Braathen, G. O., Brune, W. H., Carslaw, K. S., Craig, M. S., DeCola, P. L., Guirlet, M., Hipskind, R. S., Kurylo, M. J., Küllmann, H., Larsen, N., Mégie, G. J., Pommereau, J. P., Poole, L.R., Schoeberl, M. R., Stroh, F., Toon, O. B., Trepte, C. R., and Van Roozendael, M.: An overview of the SOLVE/THESEO 2000 campaign, J. Geophys. Res., 107(D20), 8259-8284, 2002.

Oelhaf, H., von Clarmann, T., Fischer, H., Friedl-Vallon, F., Fritzsche, C., Linden, A., Piesch, C., Seefeldner, M., and Völker, 
W.: Stratospheric $\mathrm{ClONO}_{2}$ and $\mathrm{HNO}_{3}$ profiles inside the Arctic vortex from MIPAS-B limb emission spectra obtained during EASOE, Geophys. Res. Lett., 21, 1263-66, 1994.

Oh, J. J. and Cohen, A. E.: Pressure broadening of $\mathrm{ClO}$ by $\mathrm{N}_{2}$ and $\mathrm{O}_{2}$ near 204 and $649 \mathrm{GHz}$, and new frequency measurements between 632 and $725 \mathrm{GHz}$, J. Quant. Spectrosc. Radiat. Transfer, 52, 151-156, 1994.

Perner, D., Roth, A., and Klüpfel, T.: Groundbased measurements of stratospheric $\mathrm{OClO}, \mathrm{NO}_{2}$, and $\mathrm{O}_{3}$ at Søndre Strømfjord in winter 1991/92, Geophys. Res. Lett., 21, 1367-1370, 1994.

Phillips, D. L.: A technique for the numerical solution of certain integral equations of the first kind, J. Assoc. Comput. Math., 9, 84-97, 1962.

Pickett, H. M., Poynter, R. L., Cohen, E. A., Delitsky, M. L., Pearson, J. C., and Müller, H. S. P.: Submillimetre, Millimetre, and Microwave Spectral Line Catalog, J. Quant. Spectrosc. \& Rad. Transfer, 60, 883-890, 1998.

Pyle, J., Harris, N. R. P., Farman, J. C., Arnold, F., Braathen, G., Cox, R. A., Faucon, P., Jones, R. L., Megie, G., O’Neill, A., Platt, U., Pommereau, J. P., Schmidt, U., and Stordal, F.: An overview of the EASOE campaign, Geophys. Res. Lett., 21, 1191-1194, 1994.

Raffalski, U., Klein, U., Franke, B., Langer, J., Sinnhuber, B. M., Trentmann, J., Künzi, K. F., and Schrems, O.: Ground based millimeter-wave observations of Arctic chlorine activation during winter and spring 1996/97, Geophys. Res. Lett., 25, 33313334, 1998.

Rinsland, C. P. and Goldman, A.: Search for infrared absorption lines of atmospheric chlorine monoxide (ClO), J. Quant. Spectrosc. \& Rad. Transfer, 48, 685-692, 1992.

Rodgers, C. D.: Remote Sounding of the Atmospheric Temperature Profile in the Presence of Cloud, Q. J. R. Meteorol. Soc., 96, 654-666, 1970.

Rodgers, C. D.: Retrieval of atmospheric temperature and composition from remote measurements of thermal radiation, Rev. Geophys. Space Phys., 14, 609-624, 1976.
Rodgers, C. D.: Characterization and error analysis of profiles retrieved from remote sounding measurements, J. Geophys. Res., 95, 5587-5595, 1990.

Rothman, L. S., Barbe, A., Chris Benner, D., Brown, L. R., CamyPeyret, C., Carleer, M. R., Chance, K., Clerbaux, C., Dana, V., Devi, V. M., Fayt, A., Flaud, J. M., Gamache, R. R., Goldman, A., Jacquemart, D., Jucks, K. W., Lafferty, W. J., Mandin, J. Y., Massie, S. T., Nemtchinov, V., Newnham, D. A., Perrini, A., Rinsland, C. P., Schroeder, J., Smith, K. M., Smith, M. A. H., Tang, K., Toth, R. A., Vander-Auwera, J., Varanasi, P., and Yoshino, K.: The HITRAN molecular spectroscopic database: edition of 2000 including updates through 2001, J. Quant. Spectrosc. \& Rad. Transfer, 82, 5-44, 2003.

Solomon, S., Sanders, R. W., Garcia, R. R., and Keys, J. G.: Increased chlorine dioxide over Antarctica caused by volcanic aerosols from Mount Pinatubo, Nature, 363, 245-248, 1993.

Stiller, G. P., Höpfner, M., Kuntz, M., von Clarmann, T., Echle, G., Fischer, H., Funke, B., Glatthor, N., Hase, F., Kemnitzer, H., and Zorn, S.: The Karlsruhe optimized and precise radiative transfer algorithm, Part I: requirements, justification, and model error estimation, SPIE Proceedings, 3501, 257-268, 1998.

Tikhonov, A. N.: On the solution of incorrectly stated problems and a method of regularization, Dokl. Akad. Nauk SSSR, 151, 501504, 1963.

Von der Gathen, P., Rex, M., Harris, N. R. P., Lucic, D., Knudsen, B. M., Braathen, G. O., Debacker, H., Fabian, R., Fast, H., Gil, M., Kyro, E., Mikkelsen, I. S., Rummukainen, M., Staehelin, J., and Varotsos, C.: Observational evidence for chemical ozone depletion over the Arctic in winter 1991-92, Nature, 375, 131134, 1995.

Wilms-Grabe, W., Wagner, T., Kühl, S., Beirle, S., Frankenberg, C., Grzegorski, M., Hollwedel, J., Khokhar, K., Kraus, S., Shangavi, S., Wenig, M., and Platt, U.: Monitoring of stratospheric chlorine activation with GOME OClO measurements, Proceedings on the Sixth European Workshop on Polar Stratospheric Ozone, Gothenborg 2002, European Commission-Air pollution research report, 79, 51-54, 2003. 